\title{
Interventions for the Prevention and Control of Sickle Cell Disease at Primary Health Care Centres in Gwagwalada Area Council of the Federal Capital Territory, Nigeria
}

\author{
Obiageli E. Nnodu ${ }^{1}$
}

1. Department of Haematology \& Blood Transfusion, University of Abuja, Abuja, Nigeria

$\square$ Corresponding author: Obiageli E. Nnodu, oennodu@gmail.com

Disclosures can be found in Additional Information at the end of the article

\section{Abstract}

With its population of 167 million, Nigeria has the highest burden of sickle cell disease (SCD) in the world with birth prevalence of $2 \%$ and $0.05 \%$ in adults due to deaths in early childhood. Sickle cell disease is thus a major contributor to Nigeria's "under five" mortality figures. Failure to pay attention to such a widespread condition in the population is slowing progress towards Nigeria's achievement of the Millennial Development Goals (MDG) 3-5.

Although the Federal Government set up six MDG Sickle Cell Centres in 2012 in six geopolitical zones and equipped them with variant newborn high performance liquid chromatography equipment, these centres are not carrying out newborn screening in a systematic and standardized way and the equipment is not being fully utilized. There is no universal screening of babies for SCD and identification at the primary care level. The care of SCD has been confined to tertiary health care centres with few dedicated sickle cell clinics. The average age of presentation at these centres is eight years, and there is no formal referral system of patients through the lower levels of care.

In developed countries, major benefits in the health and survival of patients with SCD have been achieved through the implementation of a few highly effective evidence-based interventions. A community-based intervention program is described which will provide parents, caregivers, and health care workers at primary health centres and ward levels with basic health education to look after patients with SCD, recognize early warning signs of complications, and institute appropriate referral mechanism to the comprehensive centres where advanced medical care can be given as necessary.

Received 07/04/2014

Review began 07/05/2014

Review ended 08/17/2014

Published 08/18/2014

C Copyright 2014

Nnodu. This is an open access article distributed under the terms of the Creative Commons Attribution License CC-BY 3.0., which permits unrestricted use, distribution, and reproduction in any medium, provided the original author and source are credited.
Categories: Internal Medicine, Epidemiology/Public Health, Genetics

Keywords: newborn screening, nutrition, prevention and control, training, genetic counselling, comprehensive care, infection prophylaxis, health maintenance, sickle cell disease, primary care

\section{Introduction And Background}

Sickle cell disease (SCD) is an inherited blood disorder, which affects children early in life often with repeated episodes of catastrophic illness and bone pains with varying periods of relative good health in between. Children with SCD are susceptible to severe infections; they have negative nutrition balance and are less able to cope with respiratory infections and diarrhoeal 
diseases as it worsens their clinical state. Less than 50\% of babies with SCD will live beyond their fifth birthday if unattended [1]. Sickle cell disease affects almost every organ system and may result in complications, such as heart disease, stroke, hypertension, and renal failure [2]. Sickle cell disease is thus fuelling better-known childhood infectious illnesses as well as adult chronic non-communicable diseases.

According to the National Demographic Survey (NDS) [3], the prevalence of SCD is $2 \%$ at birth and $0.05 \%$ in adults. With our current population of $167 \mathrm{M}$, Nigeria thus has the largest population of SCD in the world. The difference in prevalence SCD of $2 \%$ at birth and $0.05 \%$ in adults is attributable to deaths in early childhood making SCD a major contributor (8\%) to our dismal national "under five" mortality figures. Failure to pay attention to such a widespread condition in the population is affecting negatively on Nigeria's achievement of the Millennial Development Goals 3-5.

\section{Review}

\section{Statement of the problem}

The morbidity and mortality in sickle cell disease in children and adults is high [4]. The progress in understanding the molecular basis of SCD and the pathophysiological mechanisms underlying the various complications observed in SCD has not been matched by the development of effective drugs for its treatment. However, in developed countries, major benefits in the health and survival of children with SCD have been attained through the implementation of a few simple, highly effective, evidence-based interventions, such as newborn screening, counselling, prophylaxis for infection, enrollment in comprehensive care, and stroke prevention [5]. Indeed, such simple measures as health maintenance in a sickle cell clinic with prophylaxis for malaria infection, adequate nutrition, and prompt treatment of crisis and complications have been shown to be beneficial in the management of SCD, even in resource-limited settings [6]. These interventions are not available to majority of our children, and there is no coordinated effort at control of the disease. Various individuals and societies are carrying out advocacy, counselling, awareness campaigns, and sporadic population screening without planned integration into the existing health care system, and the effect of such activities have been difficult to evaluate.

The Federal Ministry of Health set up MDG Sickle Cell Centres in the six geopolitical zones and supplied these with variant newborn HPLC equipment, but these centres are not carrying out newborn screening in a systematic manner and the equipment is not being fully utilized. Thus, information about clinical features of sickle cell disease in the country is mostly derived from hospital-based cross-sectional studies. The average age of presentation of children to the hospital is about eight years [7], so whatever is being reported could be based on those who survived and may not give a good idea about the events in early childhood that cause morbidity and mortality in SCD in Nigeria.

In the absence of prospective cohorts of SCD individuals under surveillance, the current practice of extrapolation of data from research findings from developed countries with different genetic, environmental, and societal pressures is not the best for our SCD patients. Without such well-planned epidemiological studies, locally generated evidence to support policies for appropriate intervention to alleviate the plight of individuals with SCD is lacking. In the absence of universal health insurance coverage, the burden of care for this chronic illness falls on families and where more than one family member is affected, SCD places a large economic burden on the family. Given the number of families affected in the country, this burden is high.

Currently, patients with sickle cell disease are cared for in secondary and tertiary hospitals as 
well as some private health care centres and goes on without a structured, functional referral system and without integration of specific interventions for the different levels of care.

\section{Intervention for the control of sickle cell disease at community level}

The introduction of a package of interventions aimed at reducing the mortality and incidence of complications in patients with sickle cell disease will include the following:

* Raising public awareness about SCD

* Newborn screening

* Screening for sickle cell disease at primary health care centres

* Registry of patients with SCD for prospective follow up

* Prophylaxis for infection, pneumococcal vaccines, oral penicillin, use of insecticide treated bed nets, and anti-malarial

* Health maintenance and comprehensive care

* Genetic counselling of individuals with abnormal haemoglobin, i.e. AS, AC SS, SC.

* Nutrition

* Education of patients and caregivers about sickle cell disease including what to do in acute conditions before coming to the hospital.

* Optimal hydration by teaching the patients to drink enough fluids to make their urine clear and whitish without yellow colour [6].

\section{The existing health care system}

In Nigeria, health care is provided by the local government authorities through primary care clinics/hospitals. The PHC centres are run by the local government area councils, the district general hospitals, or secondary health care facilities are under the state governments, while the tertiary hospitals are under the federal government.

There is ordinarily little integration between these levels of health care but under the MDGfunded Midwives Service Scheme (MSS) [8], clusters of four PHC centres are attached to a secondary tertiary health care centre in each area council. Each PHC has four trained midwives who run shifts to provide 24-hour service and an officer who is in charge. Under Five Care is also provided at PHC level. The PHCs are linked to the communities through ward development committees whose membership include representatives from major religious bodies, a teacher, women leaders, a representative of the PHC, and general hospital.

The MSS is thus the one program that effectively provides linkage between the different levels of health care. The National Primary Health Care Development Agency provides technical assistance to states and local governments for infrastructure, policy, and monitoring and evaluation of the program. 


\section{Cureus}

\section{Description of the Federal Capital Territory}

The Territory is located in the North Central Geo-Political Zone of Nigeria. The Federal Capital Territory (FCT), Abuja is the capital of Nigeria. It occupies a land area of 7,753.9 sq. km. The FCT shares boundaries with Kaduna, Kogi, Nassarawa, and Niger States [9].

Health care is provided by the local government authorities through primary care clinics/hospitals. There are 32 primary health care centres within the FCT, seven district general hospitals, and two referral hospitals, the National Hospital and the University of Abuja Teaching Hospital (UATH). The UATH is the main referral hospital for the FCT.

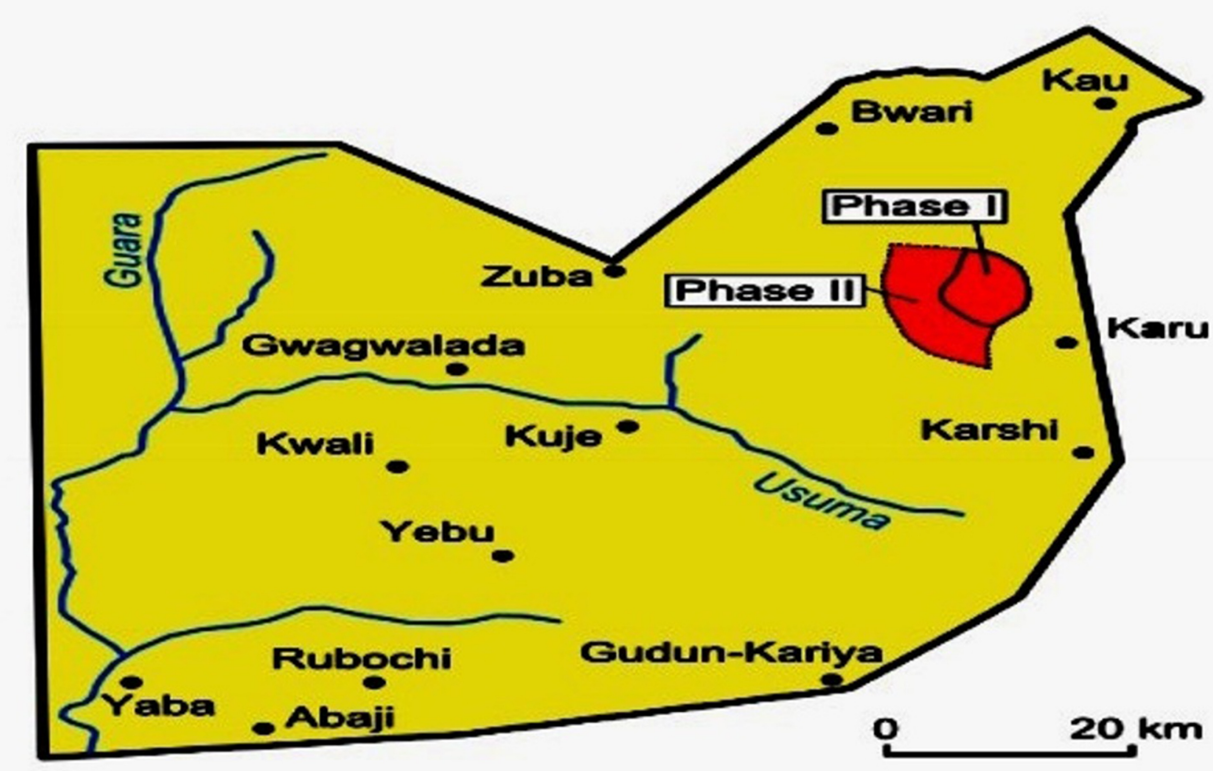

FIGURE 1: Map showing the area councils of the Federal Capital Territory, Nigeria, including Gwagwalada Area Council.

The University of Abuja Teaching Hospital is a 350-bed affiliate hospital for the University of Abuja College Of Health Sciences and a referral hospital for the Federal Capital Territory of Nigeria and surrounding states. The hospital has clinics in all the specialty areas, including haematology. Basic laboratory services are provided in haematology, chemistry, microbiology, and histopathology departments. The Department of Haematology and Blood Transfusion provides care for all patients with haematological problems, including sickle cell patients who are seen both in the paediatric and haematology clinics, with access to 24-hour emergency through the casualty or children's emergency unit.

The UATH has a well-developed referral system and research infrastructure through a number of existing programs. This elaborate referral system has given support to over 13,000 patients registered in its PEPFAR program for the provision of HIV/AIDS services. The hospital is a centre for the Midwives Service Scheme (MSS) and is linked to a cluster of four primary health centres (namely, Yimi Clinic, Kutunku Clinic, Ibwa Clinic, and Gwarko Clinic), and it thus has a well-developed infrastructure for community-based interventions through these major programs. Additionally, the hospital has over 70 consultants in major medical and surgical specialties who can deliver different aspects of comprehensive care for patients with SCD. 


\section{Cureus}

The UATH has an ethical review board that meets once every four to six weeks.

Patients with sickle cell disease are also seen in the District Generals in Maitama, Wuse, Garki, Kuje, Nyanya, Kwali, Life Camp/Gwarimpa, Kubwa, and Karu as well as a number of private hospitals and clinics.

\section{Demographics}

The population of the FCT, according to the 2006 census figures, is 1,406,239: 733,172 males and 673,067 females. According to the 2008 National Demographic Health Survey, 69.1\% of women deliver in health facilities, $70.2 \%$ were by skilled providers, and $60.9 \%$ of children in the FCT received all basic vaccinations, while $7.3 \%$ received no immunization. In the 2011 Multiple Indicator Cluster Survey:

* $41.5 \%$ of births are registered nationally;

* children aged $0-17$ constitute $47 \%$ of the population with under-fives making $17 \%$ of the population;

* $76 \%$ of children live in the rural areas while $30 \%$ of children live in urban areas;

* $54 \%$ of children have mothers with no education, while $20 \%$ have mothers with primary education and $37 \%$ have mothers with secondary education;

* $23 \%$ of "under five" children live in the poorest households, while $18 \%$ live in the richest households.

The infant mortality rate is 97 per thousand and "under five" mortality is 158 per thousand. These are essential in designing appropriate programs to reach the majority of the population at the level they can understand and afford (Figures 2, 3) [10-12].

\section{Table 6 Early childhood mortality rates}

Neonatal, post-neonatal, infant, child, and under-5 mortality rates for five-year periods preceding the survey, Nigeria 2013

\begin{tabular}{lcccccc}
\hline $\begin{array}{l}\text { Years preceding } \\
\text { the survey }\end{array}$ & $\begin{array}{c}\text { Approximate } \\
\text { time period of } \\
\text { estimated rates }\end{array}$ & $\begin{array}{c}\text { Neonatal } \\
\text { mortality } \\
(\mathrm{NN})\end{array}$ & $\begin{array}{c}\text { Post-neonatal } \\
\text { mortality } \\
(\mathrm{PNN})^{1}\end{array}$ & $\begin{array}{c}\text { Infant } \\
\text { mortality } \\
(1 \mathrm{q} 0)\end{array}$ & $\begin{array}{c}\text { Child } \\
\text { mortality } \\
(4 \mathrm{q} 1)\end{array}$ & $\begin{array}{c}\text { Under-5 } \\
\text { mortality } \\
(5 \mathrm{q} 0)\end{array}$ \\
\hline $0-4$ & $2009-2013$ & 37 & 31 & 69 & 64 & 128 \\
$5-9$ & $2004-2008$ & 43 & 42 & 86 & 83 & 162 \\
$10-14$ & $1999-2003$ & 46 & 47 & 93 & 102 & 185 \\
\hline
\end{tabular}

${ }^{1}$ Computed as the difference between the infant and neonatal mortality rates.

FIGURE 2: Table from the National Demographic Health Survey 2013 report showing figures for early childhood mortality rates. 


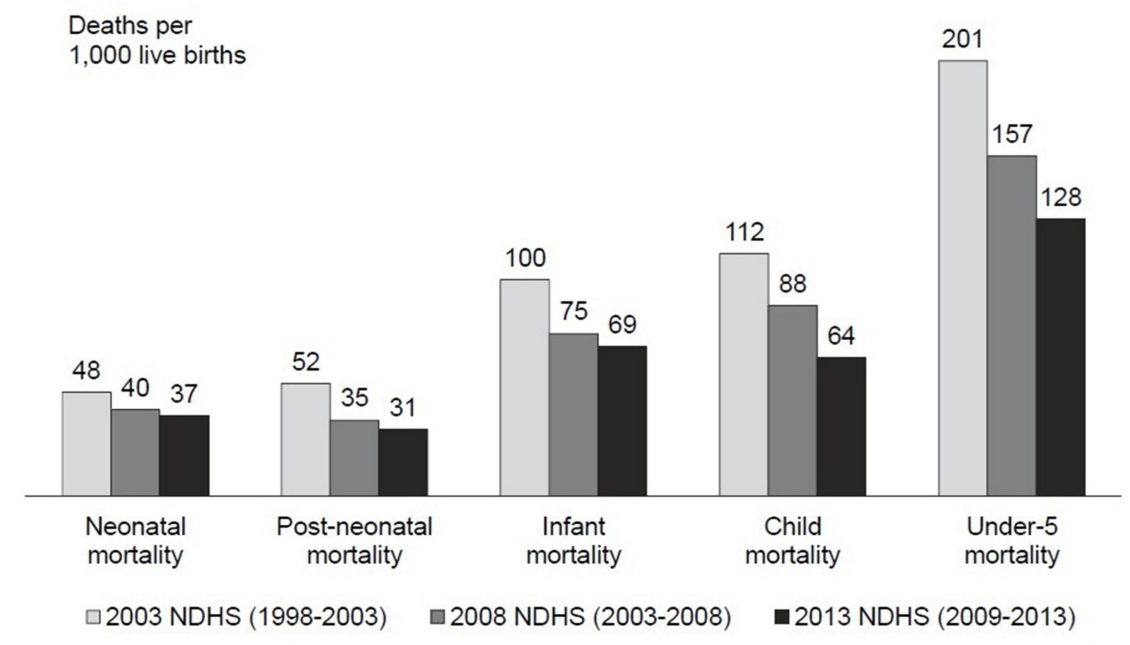

FIGURE 3: Trends in childhood mortality 1998-2013 from the National Demographic Health Survey 2013 report.

\section{Training}

Health workers should be trained in newborn screening (NBS) on how to recognise clinical phenotypes, provide counselling, diagnosis of SCD by high performance liquid chromatography, and how to track babies detected by screening. Training should also be given on patient enrollment into the paediatric and adult sickle cell clinics and the establishment and maintenance of a registry of patients in the community who have SCD, including those who have sickle cell trait. This is important for prospective follow-up.

\section{Public enlightenment and sensitisation}

Working in collaboration with the National Primary Health Care Development Agency (NPHCDA), community leaders, community resource persons, and community health extension workers, public enlightenment of residents of the following communities, Gwagwalada, Kutunku, Ibwa, and Gwarko, will be done through local radio stations.

\section{Screening}

All newborns and babies presenting to the immunization centres and other children attending the primary health care centres at Yimi Clinic, Kutunku Clinic, Ibwa Clinic, Gwarko Clinic, and the University of Abuja Teaching Hospital will be screened according to the following protocol, which has been drawn up by the Federal Ministry of Health:

* Obtain verbal consent from the parent (usually the mother)

* Collect sample through heel prick by the birth attendant as soon as possible after birth with absorbent paper 
* Obtain the following information:

a) Baby's age (to be captured on a separate sheet)

b) Baby's name and DOB on the absorbent paper

c) Date of sample collection

d) Mother's/father's name

e) Contact/mobile number of parent

f) Parent's genotype, if known

Samples are to be transported in waterproof/tight packaging using standard operating protocols to the laboratory for screening where they will be checked to see that the samples have been correctly applied, the information provided is complete, patient data entered into the registry, and sample sent for analysis of haemoglobin type by a trained person using high performance liquid chromatography machine under appropriate quality control program. A second method, such as isoelectric focusing, will be used as confirmation of positive samples.

The analysis, interpretation of results, and dispatch of results to the patient should be carried out according to the national protocol for newborn screening (NBS).

In each maternity unit or PHC, one trusted health worker will be dedicated to receiving results electronically.

Trained personnel will communicate the results to the parents. The disease will be explained to the parent from its mode of inheritance to the health care problems that may occur and how to manage them. Educational materials addressing danger signs as fever, persistent headache, abdominal pain, priapism, vomiting and diarrhoea, features of severe anaemia and chest pain with breathlessness will be provided in a language that they can understand [13-14].

All patients identified to have SCD within the area under coverage will be enrolled in a register to receive specific interventions and comprehensive care according to the national guidelines.

\section{Infection prophylaxis}

Malaria Prevention:

Malaria is associated with ill health and deaths in malaria endemic areas, such as Nigeria. Although there is no general agreement about the use of specific drug for malaria prophylaxis in children in malaria endemic areas, the Federal Ministry of Health guideline for the management of SCD in Nigeria [15] recommends health education, environmental control, indoor spraying of insecticides, distribution of insecticide treated bed nets, and chemoprophylaxis by daily proguanil, $100-200 \mathrm{mg}$ daily (under one year $-25 \mathrm{mg}$, one to three years - $50 \mathrm{mg}$, three to six years upward - $20 \mathrm{mg}$ to $100 \mathrm{mg}$ ).

\section{Oral Penicillin V:}

From two months to three years - $125 \mathrm{mg}$ bd, > three years $-250 \mathrm{mg}$ bd. This prophylaxis should be given in children up to 16 years. In patients allergic to penicillin, erythromycin in the same 


\section{Cureus}

dose will be given.

All patients should receive folate supplementation with folic acid 2.5 - $5 \mathrm{mg}$ daily.

Immunizations should be administered according to national protocol as indicated in Table 1 .

\begin{tabular}{ll}
\hline Immunization & When \\
BCG & At birth \\
OPV0 & At birth \\
OPV1 & 6 weeks \\
OPV2 & 10 weeks \\
OPV3 & 14 weeks \\
Hepatitis B1 & At birth \\
Hepatitis B2 & 6 weeks \\
Hepatitis B3 & 14 weeks \\
Haemophilus influenza & $3,6,10,14$ weeks \\
\hline DPT & $6,10,14$ weeks
\end{tabular}

Pneumococcal

conjugate 13 valent

vaccine

From 6 weeks, monthly $x 3$ doses and a booster at 12 months, followed by pneumococcal polysaccharide vaccine 23 valent from 2 yrs with booster dose 3 years later

Measles 9 months

Yellow fever $\quad 9$ months

\section{TABLE 1: Immunizations}

Schedule of immunization of children with sickle cell disease, according to the national guidelines.

\section{Stroke prevention}

Stroke is one of the most devastating complications of SCD. The incidence of stroke is 300 times higher in $\mathrm{Hb}$ SS than $\mathrm{Hb}$ AA children [16-18]. Children, two to 16 years of age, whose blood velocity by transcranial doppler ultrasound scan (TCD USS) is $\geqslant 200 \mathrm{~cm} / \mathrm{s}$ in distal internal carotid, middle, or anterior cerebral artery with steady state $\mathrm{Hb}<7 \mathrm{~g} / \mathrm{dl}$ or neutrophils $>10 \mathrm{x}$ $10^{9} / 1$ or an affected sibling are at an increased risk of stroke [16].

Children, aged two to 16 years, will be screened by TCD USS to identify those with a high risk of developing stroke. Chronic blood transfusion program has been found to reduce the TCD USS velocities in children with high risk of stroke [19-20]. This intervention is expensive [20] and beyond the capacity of countries that do not have well-developed blood transfusion services and relies on replacement or commercial donors for their blood supply. Therefore, those with 
TCD USS velocities greater than $200 \mathrm{~cm} / \mathrm{s}$ will be transfused to reduce the haemoglobin S below $30 \%$ and then placed on hydroxyurea treatment. Those with velocity of $170-199 \mathrm{~cm} / \mathrm{s}$ will have repeat TCD USS in three months and, if found to be high risk, will receive treatment as described above.

Chronic blood transfusion may be complicated by the development of antibodies to blood group $K, C, E, S, F y$, and Jk antigens. To minimize this, when possible, Hb AA group compatible blood, which has been matched for these antigens, will be used. Since the goal of blood transfusion is to reduce the concentration of $\mathrm{HbS}$ to below $30 \%, \mathrm{Hb} \mathrm{AA}$ rather than $\mathrm{Hb} \mathrm{AS}$ blood is preferred for transfusion in SCD [21-22].

\section{Nutrition and hydration}

SCD patients in sub-Saharan Africa have been shown to have fewer crisis and fever hospital visits when attention has been paid to their nutrition and adequate hydration [6]. Therefore, children identified to have SCD in these communities should be encouraged to drink a cup of water on waking up, mid-morning, and mid-afternoon under supervision and frequently during the day to ensure that the yellow colour of urine becomes white.

They should also be given a high protein diet and a nutrition package including fruits and vegetables.

\section{Conclusions}

\section{Significance}

This community-centred approach to the care of this chronic inherited blood disorder is culturally appropriate, as most people are aware of the saying that it "takes a village to bring up a child". Health intervention programs have failed because of inadequate attention to context with new vertical programs not integrating into existing ones resulting in silos and poor utilization of scarce health resource. The health seeking behaviour of the populace and pathways to health involve community resource persons, such as traditional birth attendants, chemists, and patent medicine sellers. Myths surrounding children with SCD who are recognizable by lay people in the community may make caregivers take a resigned attitude to actively care for them while waiting for the inevitable to happen. With $60 \%$ of the population living on under a dollar a day, those who would like to seek health care in the hospital cannot afford it. Consequently, many patients are seen going about in the community with telltale signs of their illnesses unattended. Introduction of a package of intervention at community level would have a number of benefits. It would debunk the myths associated with the disease, remove stigmatisation, and provide help for parents and caregivers, but more importantly, it will provide a culturally appropriate and sustainable model of care for chronic noncommunicable diseases (NCDs) which can be applied to other communities.

\section{Innovation}

The care of SCD has been confined to tertiary health care centres with few dedicated clinics. Due to the paucity of specialists with requisite training for this care, the majority of SCD are not being served. A community-based intervention program would be a deliberate attempt to provide parents, caregivers, and health care workers at PHC and ward levels with basic health education to look after patients with SCD, recognize early signs of complications, and institute appropriate referral mechanism to the comprehensive centre where advanced medical care can be given as needed.

Integration of such an intervention package into the successful MSS for NBS is innovative, as it 
will optimize the use of existing infrastructure and scarce human resource for health.

\section{Expected outcomes}

A community-based intervention program may help to mobilise the patients with sickle cell disease in these communities into the formal health system where they can receive education and counselling followed by appropriate and timely care. By introducing newborn and population-based screening, a structured referral system, and comprehensive care, the number of patients attending regular health maintenance SCD clinic at the teaching hospital will increase with consequent decrease in frequent emergency admissions due to crisis.

These interventions are expected to reduce the frequency of crisis, increase haemoglobin levels, reduce the frequency of complications, improve quality of life scores, and reduce allcause mortality in patients with SCD.

\section{Additional Information}

\section{Disclosures}

Conflicts of interest: In compliance with the ICMJE uniform disclosure form, all authors declare the following: Payment/services info: All authors have declared that no financial support was received from any organization for the submitted work. Financial relationships: All authors have declared that they have no financial relationships at present or within the previous three years with any organizations that might have an interest in the submitted work. Other relationships: All authors have declared that there are no other relationships or activities that could appear to have influenced the submitted work.

\section{Acknowledgements}

I would like to thank Professor Adekunle Adekile, HOD and Chair, Department of Paediatrics, Kuwait University, Kuwait, for reading the concept note.

\section{References}

1. Molineaux, L, Gramiccia, G World Health Organization: The Garki project : Research on the epidemiology and control of malaria in the Sudan Savannah of West Africa. World Health Organization Institutional Repository for Information Sharing. 1980, Accessed: August 1, 2014: http://apps.who.int/iris/bitstream/10665/40316/1/9241560614.pdf.

2. Rees DC, Williams TN, Gladwin MT: Sickle-cell disease. Lancet. 2010, 376:2018-31. 10.1016/S0140-6736(10)61029-X

3. National Population Commission [Nigeria]: Nigeria Demographic and Health Survey 1999. National Population Commission and ORC/Macro, Calverton, Maryland; 2000.

4. Piel FB, Patil AP, Howes RE, Nyangiri OA, Gething PW, Dewi M, Temperley WH, Williams TN, Weatherall DJ, Hay SI: Global epidemiology of sickle haemoglobin in neonates: a contemporary geostatistical model-based map and population estimates. Lancet. 2013, 381:142-51. 10.1016/S0140-6736(12)61229-X

5. Gill FM, Sleeper LA, Weiner SJ, Brown AK, Bellevue R, Grover R, Pegelow CH, Vichinsky E: Clinical events in the first decade in a cohort of infants with sickle cell disease. Cooperative Study of Sickle Cell Disease. Blood. 1995, 86:776-83.

6. Rahimy MC, Gangbo A, Ahouignan G, Adjou R, Deguenon C, Goussanou S, Alihonou E: Effect of a comprehensive clinical care program on disease course in severely ill children with sickle cell anemia in a sub-Saharan African setting. Blood. 2003, 102:834-8.

7. Brown BJ, Akinkunmi BF, Fatunde OJ: Age at diagnosis of sickle cell disease in a developing country. Afr J Med Med Sci. 2010, 39:221-5.

8. Nigeria Primary Health Care Development Agency Midwives Service Scheme . (2011). Accessed: November 20, 2014: 
http://www.who.int/workforcealliance/forum/2011/hrhawardscs26/en/.

9. Population and Map of FCT Abuja, Nation Population Commission . Accessed: August 17, 2014: http://www.population.gov.ng/index.php/fct-abuja.

10. National Population Commission (NPC) [Nigeria] and ICF International: 2013 Nigeria Demographic and Health Survey: Key Findings. The Demographic and Health Surveys (DHS) Program. 2014, http://dhsprogram.com/publications/publication-search.cfm.

11. National Population Commission (NPC) [Nigeria] and ICF Macro: Nigeria Demographic and Health Survey 2008. The Demographic and Health Surveys (DHS) Program. 2009, http://dhsprogram.com/publications/publication-search.cfm.

12. National Bureau of Statistics (NBS), United Nations Children's Fund (UNICEF), United Nations Population Fund (UNFPA), Government of Nigeria through the National Bureau of Statistics: Nigeria Multiple Indicator Cluster Survey 2011, Main Report, Abuja Nigeria . National Bureau of Statistics (NBS). 2013, Accessed: November 20, 2014: http://www.unicef.org/nigeria/Multiple_Indicators_Cluster_Survey_4_Report.pdf.

13. State of California Department of Health Services: A Parent Handbook for Sickle Cell Disease in Nigeria. Part 1: 0-6 Years. Genetics Disease Screening Program. . 2008, Adapted for Nigeria by Brown B, Adeyinka Falusi A, Jaudes P in 2012. http://scsn.com.ng/wpcontent/uploads/2014/11/Nigerian-Sickle-Cell-Handbook-0-6-years.pdf.

14. State of California Department of Health Services: A Parent Handbook for Sickle Cell Disease in Nigeria. Part 2: 6 - 18 Years. Genetics Disease Screening Program. . 2008, Adapted for Nigeria by Brown B, Falusi A, Paula Jaudes P in 2012. http://scsn.com.ng/wpcontent/uploads/2014/11/Nigerian-Sickle-Cell-Hand-Book-6-18-years.pdf.

15. Department of Public Health, NCD Control Programme, Abuja: Federal Ministry of Health National Guideline for the Control and Management of Sickle Cell Disorder. Federal Ministry of Health. 2012, pp 1-61. Accessed: August 18, 2014: http://scsn.com.ng/wpcontent/uploads/2014/11/National-Guideline-for-the-Control-and-Management-of-SickleCell-Disease.pdf.

16. Ohene-Frempong K, Weiner SJ, Sleeper LA, Miller ST, Embury S, Moohr JW, Wethers DL, Pegelow CH, Gill FM: Cerebrovascular accidents in sickle cell disease: Rates and risk factors . Blood. 1998, 91:288-94.

17. Adams RJ, McKie VC, Brambilla D, et al.: Stroke prevention trial in sickle cell anemia . Control Clin Trials. 1998, 19:110-29.

18. Webb J, Kwiatkowski JL: Stroke in patients with sickle cell disease . Expert Rev Hematol. 2013, 6:301-16. 10.1586/ehm.13.25

19. Lee MT, Piomelli S, Granger S, Miller ST, Harkness S, Brambilla DJ, Adams RJ; STOP Study Investigators: Stroke Prevention Trial in Sickle Cell Anemia (STOP): Extended follow-up and final results. Blood. 2006, 108:847-52.

20. Wayne AS, Schoenike SE, Pegelow CH: Financial analysis of chronic transfusion for stroke prevention in sickle cell disease. Blood. 2000, 96:2369-72.

21. Lasalle-Williams M, Nuss R, Le T, Cole L, Hassell K, Murphy JR, Ambruso DR: Extended red blood cell antigen matching for transfusions in sickle cell disease: a review of a 14-year experience from a single center (CME). Transfusion. 2011, 51:1732-9. 10.1111/j.15372995.2010.03045.x

22. Vichinsky EP, Luban NL, Wright E, Olivieri N, Driscoll C, Pegelow CH, Adams RJ; Stroke Prevention Trail in Sickle Cell Anemia: Prospective RBC phenotype matching in a strokeprevention trial in sickle cell anemia: a multicenter transfusion trial. Transfusion. 2001, 41:1086-92. 